\title{
Introduction: the problem of EU-India relations
}

\section{Pascaline Winand and Marika Vicziany}

The European Union (EU)-India relationship has variously been characterized as a relationship 'in desperate need of some success' (EUAsia Centre and FRIDE 2011), 'a relationship between two unequals' (EUEAPP media 'elite' respondent), 1 'a loveless arranged marriage' or a 'reluctant relationship' (Khandekar 2011). From an EU perspective, it remains 'an underexploited two-way relationship' which suffers from high tariff barriers in India as well as EU import ceilings and restrictions (interview with EU Delegation official, New Delhi, October 2011). From an Indian perspective, the relationship is 'very amicable'. It is a 'nonproblematic, feel-good relationship' (EUEAPP, political 'elite' respondents; civil society 'elite' respondent) but is also 'not very active' (EUEAPP, civil society 'elite' respondent) and lacks momentum (EUEAPP, business 'elite' respondent). An Indian climate campaigner recently described it as 'a stable relationship, not deteriorating but pretty much stagnant for the past, at least one decade or so' (EUEAPP, civil society 'elite' respondent).

So why bother studying European-Indian relations? Why this book? When we embarked upon this project, we felt that the EU-India relationship was understudied and suffered from clichés that were repeated time and again from one publication to the next. One of these was that India only began to take European integration seriously in the 1990s. We thought that an in-depth study was needed to put current developments in EU-India relations in historical perspective in the hope that a better understanding of the evolution of EU-India relations might form a sounder basis for analyzing current developments. Another reason was the sheer magnitude of the economic, political and security interests at play in this relationship in the 21st century. There is enormous scope for growing investment and trade on both sides. For India, the EU remains the largest trading partner, but the percentage of Indian exports going to the EU and of India's imports from the EU has fallen significantly since the 1990s. In 1996, the EU bought 26 percent of India's exports and 30 percent of India's imports originated from the EU. By contrast, 17 percent of Indian 
exports now go to the EU and 11 percent of Indian imports come from the EU (see Chapter 7 in this volume). India's trade with the EU is growing more slowly than with other parts of the world such as China and Korea. As for India's share in EU external trade, it remains limited although it has grown since the 1990s. In 1996, trade with India amounted to 1.3 percent of EU external trade. In 2011 India represented 2.5 percent of total EU external trade, as compared with 13.3 percent for China. While the EU is India's largest source of foreign direct investment (FDI), such investment represents a paltry 1.1 percent of EU investments worldwide (EC 1996; Bonnafont and Bazard 2010, p.171; von Muenchow-Pohl 2012; also see Chapter 8 in this volume).

While there is potential for significant growth in trade and investment, both the EU and India face the challenge of how to encourage such developments while keeping their populations satisfied. The Free-Trade Agreement (FTA), also called a Broad-based Trade and Investment Agreement, which has now been on the negotiating table since 2007, could 'cut import duties on over 90 percent of all tradable goods during the next 10 -year period and scale up bilateral trade in goods and services to $\$ 200$ billion by $2013^{\prime 2}$ (Euractiv 2012). Yet Indian officials warn that huge tariff cuts in the industrial and agricultural sectors could lead to massive unemployment and undermine India's trade balance. Non-governmental organizations (NGOs) such as Oxfam have criticized the EU, 'backed by multinational pharmaceutical companies [for] trying to impose new intellectual property (IP) and investment rules in India, which would result in drastically higher medicine prices for the poorest people across the globe' (Euractiv 2012). India indeed produces 'over two-thirds of all generic medicines' and these are in turn sold at affordable prices to 'poor and middle income countries' (Euractiv 2012). Fearing its potential harmful impact on its domestic economy, India finds it difficult to yield to EU calls for lower duties for European automotive exports to India. Equally, the EU has resisted India's calls for better access of its information technology (IT) service providers to the EU to protect its own market (von MuenchowPohl 2012). The stakes are thus high and not just for India, the EU and their populations.

This is also the case in the area of climate change and energy. India's large population, more than 1.2 billion in 2012, coupled with high growth, could lead India to increase its energy consumption sevenfold. India has begun to address the problem with its National Action Plan on Climate Change, which seeks ways of attaining a more sustainable growth including the use of solar energy (Devare et al. 2009, p. 4). Understandably, calls on the part of the EU to agree on legally binding commitments on $\mathrm{CO}_{2}$ emissions have been met with reluctance in Delhi, which criticizes the EU 
tendency to bunch developed and developing countries together in supporting the costs of reducing emissions, although their circumstances are very different. The 2009 United Nations Climate Change Conference in Copenhagen showed the extent of the divergences between developed and developing countries, and in particular, a certain incapacity on the part of the EU to coordinate its position with India on climate change. The 2011 Durban conference did, however, show more cooperation between India and the EU.

In a roundtable on 'Prospects for EU-India Relations' in Brussels, one of the participants felt that there were 'not enough irritants' in the relationship, and wondered if perhaps debate on the FTA could 'jump start the relationship' (EU-Asia Centre and FRIDE 2011). But there is more to EU-India relations than trade and investment. An Indian member of the National Human Rights Commission of India has criticized the EUIndia summits as an exercise that 'closes its eyes on several embarrassing realities [in fear] that the trade relationships might be affected' (EUEAPP, civil society 'elite' respondent). Yet it is perhaps by reaching a better understanding of these realities that the relationship, including trade and investment, might reach its full potential.

India and the EU have concluded many agreements since the 1970s, which have progressively covered a wide gamut of issues. Starting with trade, the range of issues enlarged from agreement to agreement to include investment and cooperation in development, industry, science and technology, environmental and energy policies, higher education, culture and telecommunications and electronics. India and the EU have also developed a political dialogue with discussions ranging from human rights, democracy, counterterrorism, drug trafficking, nuclear non-proliferation, to many other issues. In fact, it would seem that few aspects of the relationship have been left uncovered. The problem is perhaps not so much in having an exhaustive relationship covering every aspect of EU-India relations, as in implementing the various agreements that have been concluded.

In the words of one Indian professor, the relationship could ideally lead to the construction of 'a new world order in the 21 st century, [. . . ] stable, [. . .] based on democracy and liberalism, support to the poorer constituencies in the world within Africa and parts of Asia, working on science and technology, [. . .] climate change' and the 'restructuring of the United Nations' (EUEAPP, civil society 'elite' respondent). An Indian publisher recently spoke of her wish for EU-India cooperation to become 'like a foil against the combative South Asia and Europe' (EUEAPP, business 'elite' respondent). A foreign editor of the Hindustan Times saw potential in having EU-India regional dialogues with Africa, in which Europe 
possesses enormous expertise, and perhaps also with the Arab world, as 'India's knowledge of the Arab world is very strong in the Persian Gulf' but wanting in the Maghreb (interview with Indian journalist, Hindustan Times, New Delhi, October 2011). Other Indian civil society and political leaders thought EU-India cooperation could help in 'development and state building in many new states in Africa and Asia', 'solv[ing] the African debt crisis' and in dealing with terrorism, anti-piracy and global warming (EUEAPP, civil society 'elite' respondent; political 'elite' respondent; interview with Indian Ambassador, New Delhi, October 2011). But is this wishful thinking? And do the worldviews of India and the EU sufficiently overlap to bring about such cooperation?

Official EU speeches frequently emphasize the similarities between the EU and India, then go on to highlight shared beliefs and potential cooperation between the EU and India in the world. President of the European Commission, José Manuel Durão Barrosso, told an Indian business audience in Mumbai in February 2012 that the EU and India, in spite of their differences, had much in common. India, he said, 'has 28 States, the EU will have 28 states as from next year, after Croatia joins. You have 22 official languages, 23 if we consider English and the EU also has 23 official languages.' He further emphasized a 'shared belief in the benefits of a rules-based multilateral system' and a 'common deep commitment to supporting fair and balanced trade rules for all'. He explained that he saw India and Europe as 'natural partners in a globalized and changing world' which 'together [... could] make a major contribution to finding and implementing solutions to common challenges, from demographic issues to climate change' (Barroso 2012). In a similar, but more critical vein, and with more of a focus on EU member states, albeit only some of the largest ones, the French Ambassador to India and one of his advisors, wrote that (Bonnafont and Bazard, 2010, p. 171):

On paper, the list of factors drawing Europe and India together is impressive. Each is the cradle of an old civilization. Countries like Portugal, Spain, the Netherlands, Denmark, the United Kingdom and France have been trading with India for close to five centuries. British colonization left India with a European language as well as European political, legal, educational and economic institutions. [....] The Indian 'renewal' was born of the work of thinkers heavily influenced by Western culture such as Tagore, Vivekananda, and Gandhi. And the 'temptation of India' marked more than one European, from Arthur Schopenhauer to Romain Rolland and André Malraux, and more recently, writers such as Catherine Clément.

Arguing that the 'strong links between Europe and India continue today', Bonnafont and Bazard recommended for European policy towards India to use the advantages of member states such as important financial 
and human exchanges [...] between India and the United Kingdom; French expertise in defence and civil nuclear projects; German industrial, scientific and technological dynamism; and the British [development] cooperation budget (which is four times higher than that of the Union itself)'. The article also mentioned the opening of an Indian Mission to the European Economic Community (EEC) in the early 1960s and some of the agreements and dialogues entered into since the 1970s in EEC/ EU-India relations. Notwithstanding such commonalities, the authors observed that significant divergences between India and the EU remained, as exemplified by their behavior in tackling global issues such as climate change, the reform of the UN, terrorism, human rights and nuclear questions (Bonnafont and Bazard 2010, pp.172-6). This is an observation that we find frequently reiterated in articles and conferences on both the Indian and the EU sides. In October 2009, the European Union Institute for Security Studies (EUISS) and the Indian Council of World Affairs (ICWA) held a forum on Effective Multilateralism at the ICWA in New Delhi. The participants agreed that India and the EU had much in common in terms of how they viewed 'multiculturalism, diversity and plural societies'. Their conclusions, which looked like a juxtaposition of different worldviews, showed an 'agreement to disagree' on many issues. For example, India's reluctance to force democracy on its neighbors and its choice to foster such democracy 'through its own example' was contrasted with the EU 'model of democracy promotion' and its 'democratic conditionalities'. India's preference for refraining from intervening in the affairs of other states was contrasted with the EU's more interventionist tendency to step in on conflict situations with humanitarian aid under the justification of the principle of the Responsibility to Protect (R2P). These divergences, the EUISS remarked, originated in the fact that 'the EU is a "new" supranational entity and India is a sovereign state. Thus they adopt fundamentally different approaches to addressing issues of common concern' (Devare et al. 2009). Other analysts have similarly pointed to different definitions of multilateralism. From a French perspective, while India makes use of international institutions to 'ensure that the strong do not always prevail over the weak' and sees them mostly as 'venues for defending national interests', Europeans view multilateralism as entailing 'a willingness to give up a portion of one's sovereignty in the interest of a collective management of common affairs' (Bonnafont and Bazard 2010, p. 175).

In spite of these divergent views and the many challenges in the relationship, what has EU-India cooperation achieved over time, and how? And where is the relationship going? 


\section{STRUCTURE AND METHODOLOGY}

We have chosen to answer these questions in two different ways. Firstly, by looking at the evolution of EU-India relations since the European Communities took their first steps and secondly by conducting in-depth investigations of particular themes in EU-India relations.

\section{Methodology}

For the first part of the book we used the Archives of the Council of the EU, the European Commission Historical Archives and the European Parliament Archives in Brussels, as well as the Archives of the Public Record Office in London. All archives contained a wealth of information about EEC-India relations from the 1950s to the 1970s, including memos from the Indian Mission to the European Union and extensive descriptions of conversations between Indian and European officials. In New Delhi, Pascaline Winand gathered archival material, as well as secondary literature difficult to obtain outside of India, at the Indian Council of World Affairs' Library and at the Ministry of External Affairs' Library. In-depth interviews ${ }^{3}$ were conducted by Professor Winand in Brussels at the European Commission, the European Parliament and the Embassy of India to Belgium, Luxembourg and the European Union. In New Delhi, Marika Vicziany and Pascaline Winand interviewed prominent Indian journalists, officials from the Indian Ministry of External Affairs and the Indian Commission for Agricultural Costs and Prices, the director and deputy director of the ICWA, various economists and Indian professors at various universities. Pascaline also interviewed senior officials from the different sections of the Delegation of the European Union to India; the European Commission Directorate-General for Humanitarian Aid and Civil Protection (ECHO), Regional Support Office, South Asia and the European Business and Technology Centre. In Melbourne, Delhi and Patna, Marika interviewed the former director of the Centre for the Study of Global Governance at the London School of Economics (LSE), as well as Indian ambassadors and scholars on the history and perceptions of the EU and India. She also consulted policy advisors to the Government of India (GOI) and various journalists about agricultural prices and Indian lobbies against an EU-India FTA. In Kolkata, Marika presented the results of her research on Indian and EU agricultural interests and the forthcoming FTA to a roundtable organized by the Institute of Development Studies Kolkata (IDSK). We were also fortunate to be able to use the data from the interviews on Indian perceptions towards the EU generated by the transnational comparative project 'The EU in the Eyes of 
Asia-Pacific' (EUEAPP) at the National Centre for Research on Europe (NCRE), University of Canterbury, New Zealand. The research team from Jawaharlal Nehru University, New Delhi, gathered the data from India. ${ }^{4}$ In September 2012, Pascaline Winand and Marika Vicziany also tested out their ideas by running a half-day seminar at Monash University about their preliminary conclusions.

\section{Structure and Contents}

Chapters 1 to 5 cover the evolution of the EU-India relationship from the late 1940 s to the beginning of the 21 st century. The first question we ask in Chapter 1 is whether Indian elites showed any interest in regional endeavors in Europe and in other parts of the world after World War II, even before the creation of the European Communities. The results of our research were surprising for reasons we explain in the chapter. Even before the opening of an Indian Mission to the EEC in 1962 we discovered high levels of anxiety amongst Indian official and business circles. How would the EEC impact on India? In particular, how would preferential treatment of the EEC's overseas territories affect Indian trade? In these early years, the EEC only accorded marginal attention to India - something that no doubt fueled Indian anxieties. Chapter 1 analyzes how the GOI and business communities gradually broke away from old colonial patterns and developed new strategies via negotiations in the General Agreement on Tariffs and Trade (GATT), Indian lobbying of EEC member states and discussions within the British Commonwealth.

How did these early scenarios change when the British applied to join the EEC? This is the subject of Chapter 2. Given that Britain had been India's largest market for many decades, how did India seek to protect its interests? The first British application to enter the EEC in 1963 failed, but did that reduce Indian concerns? Manmohan Singh, who would later become prime minister of India from 2004 to 2014, had just completed his D. Phil. in economics from Oxford University in 1962 and wrote an assessment of India's concerns in the Journal of Common Market Studies (JCMS). The ICWA, a think tank with close ties to the Indian foreign policy elite, commissioned a study on the economic and political consequences of the EEC for India. Indian lobbying continued unabated to salvage some of the concessions obtained during the negotiations for British entry. The returns were disappointing and in Chapter 2 we ask why a commercial cooperation agreement between India and the EEC did not eventuate at this time.

Turning to the early 1970s, the British application to join the EEC eventually succeeded (it was the third attempt) and one outcome was a 
Commercial Cooperation Agreement (CCA) between India and the EEC. In Chapter 3 we ask how British, EEC and Indian lobbying intersected to bring this about, almost a decade after it had first been proposed. Were Indian anxieties of the previous decades justified when we consider EEC policies towards Asia and the EEC Generalised Scheme of Preferences (GSP)?

Chapter 4 examines the implementation of the CCA and deals with the puzzling problem of why more and more agreements were necessary. In particular, we ask what the objectives were of the new Commercial and Economic Cooperation Agreement (CECA) signed in 1981. We also ask what the impact of the agreements of 1971 and 1981 were and who benefited from them. During the 1980s, the European Commission opened a delegation in New Delhi. Did this mean that the European Commission was, at last, taking India more seriously?

Chapter 5 analyzes the changes that the end of the Cold War brought about in EU-Indian relations at a time when the EU was evolving as an economic and monetary union. The 1990s were also the start of the liberalization of the Indian economy and in 1998 India emerged as an unambiguous nuclear power after the tests of May that year. How did these forces interplay? What happened to the old irritants in the relationship? Were there new irritants? The 1990s saw yet another agreement between the EU and India, namely the 1994 Cooperation on Partnership and Development and a Joint Statement on Political Dialogue. Did these new arrangements make any difference to the relationship?

In contrast to the first five chapters of this book, the last five approach the question of EU-India relations thematically. Here we make a special effort to not only understand Indian reactions to EU initiatives and policies, but also consider the on-the-ground implications of EU-India interactions. The chapters are written largely from an Indian perspective because to understand the reservations or enthusiasm that India may have for any particular collaboration, a broad range of factors needs to be taken into consideration, including the social and political sensitivities that dominate the world's largest democracy. In particular, given the hybrid nature of modern India - a dynamic economy with high technological capacities counterbalanced by extreme poverty and discrimination affecting over 40 percent of the population - decisions at the national and state level have to consider the reactions of many sections of the population, but in particular the poor, working class, unemployed and disadvantaged. Indian policy directions may be ultimately determined by the political elites but these are informed by the final impact of these on the electorate. The recent elections held in India in May 2014 which brought the Bharatiya Janata Party (BJP) to power, are likely to confirm 
the stalemate over the EU-India FTA. The new prime minister Narendra Modi has accorded little attention to Europe and the opposition of the BJP to FTA negotiations under the previous government does not augur well for a successful conclusion of an EU-India FTA (Khandekar 2014 and Chapter 8 in this book). This is a particularly good example of how the risks of policymaking in the dynamic political circumstances of India can delay all decision-making. This is not a criticism of India but rather a pragmatic assessment of what happens for good reasons. Nobody would wish the Indian political process to speed up at the cost of destabilizing such a large and strategically important country.

Bearing these issues in mind, we have developed five thematic chapters that capture some of the complexities of the EU-India relationship. Our focus has been largely on the situation in recent years, although where relevant we refer to earlier periods and issues. When we commenced our research, we had no clear idea what the final arguments or conclusions would be. What we did know was that specific chapters were needed on the following five areas of high national interests: EU and Indian perceptions of the challenges of implementing any meaningful collaboration; the extent to which the needs of the agrarian sectors in Europe and India could be met simultaneously; the opportunities for European and Indian industrial collaboration; the tensions between European and Indian national interests and how these were reflected in approaches to global security issues; and the relationship between EU and Indian aid programs. These chapters make extensive use of case studies to show the divergence and convergence of European and Indian interests and the interaction between high policy decisions in Brussels and New Delhi and Indian lobbies and interest groups.

The questions that informed these five thematic chapters were fundamentally very similar. What is in the national interest of India and how does this match the interests of the EU and its member states? In defining the Indian national interests, we considered the specific needs of small and rich farmers, small and large industries, the poor and the risks of increased poverty and unemployment from further liberalization of trade and investment. These questions were placed into the context of the competitiveness of the Indian economy relative to the competitiveness of the European Union.

On the EU side, the main question was how EU policies such as the FTA might impact on India. This proved to be an extremely difficult question because all the sources that we consulted complained bitterly about the lack of transparency in the development of the FTA that is still under discussion. The history of the proposed EU India FTA thus far, has been of different European and Indian interest groups lobbying to make their 
voices heard in order to influence policy outcomes. Over time, the policy outcomes have become increasingly uncertain because the FTA was not signed before the 2014 Indian national elections and now the new Indian government is too busy defining the details of its many other policies. In the meantime, there appears to be a total shutdown on any public discussions in Europe or India about the drafts that the Joint Working Party might have been working on. These drafts have not been seen outside the narrow policy elites that have been working on the proposed FTA.

The order in which these thematic chapters appear is significant. We begin, in Chapter 6, with the question of how India and the EU have perceived each other. Both sides have come up with plenty of excuses to explain the absence of concrete achievements. At the same time, both parties also have complex institutional mechanisms and a wide range of players that must be satisfied. This complexity needs to be taken seriously, because as the following chapters show the success of any collaboration ultimately depends on finding areas in which European and Indian interests and competencies are complementary rather than competitive.

The following chapter on EU-Indian agriculture, Chapter 7, is the first of our case studies. Despite the sophistication of the Indian economy today, some 70 percent of the population continues to live in villages and more than 50 percent of the Indian workforce depends directly on agricultural employment. This pitches Indian needs against some of the oldest industrial economies in the world, namely Britain, France and Germany. Yet despite two hundred years of industrialization, the EU continues to maintain high subsidies for European farmers who represent only a small proportion of the population but are politically powerful all the same. Given this divergence of national interests and the current uncertainties of the global economy, it is perhaps not surprising that our conclusions about EU-Indian agricultural cooperation are pessimistic.

Chapter 8 asks whether the complementarities in trade, industry and investment are more promising than in the agrarian sector. We ask what the inherent strengths of European and Indian industry are, and where they sit in the new globally competitive economy that has emerged in the last decade. Our main focus in this chapter is on FDI. Traditionally, the European economies have been strong investors in India. How has that changed? On the other hand, Indian companies have emerged as major multinational players. Where do they sit in the European landscape? In answering these questions we consider the role of European and Indian technologies and how they might come together to challenge third markets. We use the case study of the chemical industry in Europe to show the speed with which an entrenched industry such as this can quickly become inefficient and uncompetitive. Chemical manufacture appears to 
be relocating to the Middle East and Asia but new research tells us that Europe can still play a critical role because of its commitment to developing green technologies and alternative energy sources. The available evidence suggests that, for the reasons we explore in Chapter 8, EU-India cooperation may indeed have a future by bringing together low cost Indian production with EU green technologies.

In probing the EU-India relationship, Chapter 9 focuses on questions of national security. In 1994 the European Commission released a policy document called 'Towards a New Asia Strategy', which suggested that the EU relationship with India should go beyond mere economics and business into broader considerations. This was perhaps a high risk and overly ambitious declaration given the different regional security scenarios that confront the Europeans and the Indians. We decided to test out the realism of this new policy by considering three case studies to reveal the nature of the EU-India interactions: the Galileo project, EU reactions to the US-Indian civilian nuclear deal, and EU and Indian reactions to Iran's refusal to allow a full and proper scrutiny of its nuclear facilities. The Galileo project held out the prospect of giving us another perspective on the long-term possibilities of EU-Indian technical and scientific collaboration while the other two case studies allowed us to locate the EU-India relationship within the wider context of EU and Indian policies on the US, Iran and China. We did not approach this research with any preconceptions and so our findings were surprising to us - we concluded that EU and Indian orientations to national security were fundamentally incompatible because of the divergent realpolitik that drives country policies.

The final thematic chapter, Chapter 10, looks at the changing nature of EU-India development cooperation, and provides a preliminary assessment of EU aid in the lead-up to the conclusion of the 2007-2013 Country Strategy Paper (CSP). It charts the course of EU-India development relations since the 1970s when the EU was a major aid donor to India at a time when India was still struggling to benefit from the Green Revolution. Today, as with many other themes that we have explored in this volume, the India-EU relationship is being reversed. India is making its mark as a global aid donor, and the EU is facing great internal difficulties leading to austerity measures that compel it to constrain its foreign expenditures. Given this, will there still be a partnership in this area when the EU reviews its aid program to India in 2014?

Our conclusion identifies strengths and vulnerabilities in both India and the EU. It explains the current state of EU-India relations by looking at the different stages that gradually led the EU and India to have a more equal relationship today. In many ways, the EU-India relationship that has emerged during the last decade reflects the shifting 
global balance of economic and political power towards Asia. Yet this changed equation has not rendered the EU weak and irrelevant - it represents too great a proportion of the world's economy and people for that to be the case. It also remains, as we have argued, a center of advanced technologies that are urgently needed by India and other emerging economies. And finally, as we write these words we cannot but reflect on the recent decision of the Norwegian Nobel Committee to award the Nobel Peace Prize to the European Union. The original impetus behind the foundation of the European Community was the deep-seated yearning for peace in Europe, after two major world wars and many other bloody conflicts. For all its current difficulties, we should not lose sight of this important fact. Perhaps the EU-India relationship could develop into something that was less concerned with accessing each other's lucrative markets and more about working together to foster regional and international cooperation for the benefit of civilian populations in Asia, Europe and beyond.

\section{NOTES}

1. The data for some of the interviews from India quoted in this chapter was generated by the transnational comparative project entitled 'The EU in the Eyes of Asia-Pacific' (EUEAPP) led by Dr. Natalia Chaban and Professor Martin Holland from the National Centre for Research on Europe (NCRE), University of Canterbury, New Zealand. Supported through the years by the European Commission Jean Monnet funding and the Asia-Europe Foundation (ASEF), the project has been undertaken in 22 locations since 2002. This systematic investigation explores how the EU has been framed by local news media (press and television) and compares this with perceptions of the EU held by the general public and national stakeholders. The project research team includes researchers from leading universities in the Asia-Pacific.

2. All dollar figures in this volume are given in US dollars, unless otherwise stated.

3. A total of 35 interviews were undertaken for this project: nine in Brussels (Professor Winand, February and November 2011), 21 in Delhi (Pascaline Winand, October 2011 and Marika Vicziany, July 2012), three in Patna (Marika Vicziany, July 2012) and two in Melbourne (Marika Vicziany, July 2012 and April 2014). All but one have been kept anonymous for reasons of confidentiality. In the individual chapters we indicate where information has been based on these interviews. The interviews are not included in the reference sections.

4. A large number of interviews (37 in all) were transcribed for the Indian part of that project. These interviews were conducted in 2010. For more details see endnote 1.

\section{REFERENCES}

Barroso, J.M.D. (2012), 'EU-India: A Strategic Relationship in an Evolving World', FICCI, Mumbai, India, 13 February. Available at: http://europa.eu/ rapid/press-release_SPEECH-12-90_en.htm. 
Bonnafont, J. and G. Bazard (2010), 'The European Union Seen From India', Les Cahiers du Quai d'Orsay, 2 (Winter), pp. 170-77.

Devare, S.T., Á. de Vasconcelos and L. Peral (2009), 'Report on the India-EU Forum. Effective Multilateralism', European Union Institute for Security Studies, Sapru House, New Delhi, 8-9 October.

EU-Asia Centre and FRIDE (2011), 'Roundtable on Prospects for EU-India Relations', Brussels, 23 November.

Euractiv (2012), 'EU-India Trade Deal Not Yet in Sight', 10 February. Available at: www.euractiv.com/global-europe/eu-india-fta-sight-news-510711.

European Commission (1996), EU-India Enhanced Partnership, Communication from the Commission, COM(96) 275 final, Brussels, 26 June.

Khandekar, G. (2011), 'The EU and India: A Loveless Arranged Marriage', FRIDE Policy Brief 90 (August).

Khandekar, G. (2014), 'EU-India Engagement must be "prioritized urgently", The Parliament Magazine, 20 June. Available at: www.theparliamentmagazine. eu/articles/news/eu-india-engagement-must-be-prioritised-urgently.

von Muenchow-Pohl, B. (2012), 'EU Relations With China and India: Courting the Dragon, Wooing the Elephant'. Available at: http://carnegieendowment. org/2012/08/23/eu-relations-with-china-and-india-courting-dragon-wooingelephant. 